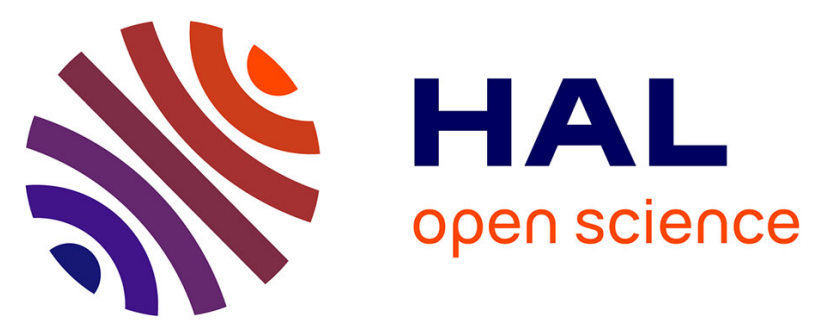

\title{
Spatiotemporal changes in flying insect abundance and their functional diversity as a function of distance to natural habitats in a mass flowering crop
}

Benoît Geslin, Melissa Oddie, Morgane Folschweiller, Gaëlle Legras, Colleen L. Seymour, F.J.Frank van Veen, Elisa Thébault

\section{To cite this version:}

Benoît Geslin, Melissa Oddie, Morgane Folschweiller, Gaëlle Legras, Colleen L. Seymour, et al.. Spatiotemporal changes in flying insect abundance and their functional diversity as a function of distance to natural habitats in a mass flowering crop. Agriculture, Ecosystems and Environment, 2016, 229, pp.21-29. 10.1016/j.agee.2016.05.010 . hal-01327223

\section{HAL Id: hal-01327223 \\ https://hal.sorbonne-universite.fr/hal-01327223}

Submitted on 6 Jun 2016

HAL is a multi-disciplinary open access archive for the deposit and dissemination of scientific research documents, whether they are published or not. The documents may come from teaching and research institutions in France or abroad, or from public or private research centers.
L'archive ouverte pluridisciplinaire HAL, est destinée au dépôt et à la diffusion de documents scientifiques de niveau recherche, publiés ou non, émanant des établissements d'enseignement et de recherche français ou étrangers, des laboratoires publics ou privés. 
ORIGINAL PAPER

2 Spatiotemporal changes in flying insect abundance and their functional diversity as a

Benoît Geslin ${ }^{\mathrm{a}, \mathrm{b}}$, Melissa Oddie ${ }^{\mathrm{c}}$, Morgane Folschweiller ${ }^{\mathrm{b}, \mathrm{d}}$, Gaëlle Legras ${ }^{\mathrm{b}, \mathrm{e}}$, Colleen L.

6 Seymour $^{\mathrm{f}, \mathrm{g}}$, F.J. Frank van Veen ${ }^{\mathrm{c}}$ and Elisa Thébault ${ }^{\mathrm{b}}$

a Institut Méditerranéen de Biodiversité et d'Ecologie marine et continentale (IMBE), Aix

9 Marseille Université, CNRS, IRD, Avignon Université, Faculté des Sciences et Techniques

St-Jérôme, Avenue Escadrille Normandie Niémen, Case 421, F-13 397 Marseille Cedex 20,

11 France

${ }^{\mathrm{b}}$ Institute of Ecology and Environmental Sciences - IEES Paris (UMR 7618, UPMC, CNRS,

IRD, INRA, UPEC, Paris Diderot), Université Pierre et Marie Curie, 7 quai St Bernard, 75005

14 Paris, France

${ }^{c}$ Centre of Ecology and Conservation, College of Life and Environmental Sciences,

University of Exeter, Penryn Campus, Penryn, Cornwall, TR10 9FE, UK

${ }^{\mathrm{d}}$ Laboratoire de Zoologie, University of Mons, Mons, Belgium

${ }^{\mathrm{e}}$ University of French Polynesia - UMR-241 EIO (UPF, IRD, Ifremer, ILM) Papeete, French

Polynesia

${ }^{\mathrm{f}}$ South African National Biodiversity Institute, Kirstenbosch Gardens, PVT Bag X7,

21 Claremont, 7735, South Africa

$22{ }^{\mathrm{g}}$ DST/NRF Centre of Excellence at the Percy FitzPatrick Institute of African Ornithology,

23 Department of Biological Sciences, University of Cape Town, Rondebosch, 7701

24 Corresponding author: Benoît Geslin

25 E-mail: benoit.geslin@imbe.fr 


\section{Abstract}

To meet the dietary requirements of a burgeoning human population, the demand for animaldependent crops continues to grow. To meet the demand, intensive farming practices are used. The gains in food production associated with agricultural intensification may be offset by its detrimental effects on pollinator populations through natural habitat fragmentation and pesticide use. Abundance and species richness of pollinators have been found to decrease with increasing distance to natural habitat in agroecosystems, reducing crop yields. A key aspect of crop pollination lies in the diversity of functional traits (functional diversity, FD) of flowervisitor communities within crop fields. Higher FD allows improved pollination success through complementarity between flower-visitors' morphology, phenology and behaviour.

Many studies reported negative effects of increasing distance to natural habitats on the abundance and richness of flower-visitor communities, but the link between FD and natural habitat isolation is less well understood. Also, a more complete understanding of the functional traits of flower-visitor communities within crops should consider potential variations through time. Differences in resources availability between seasons are important in tropical areas and could modify ecological responses of flower-visitor communities to isolation. In this study, we surveyed the Hymenoptera and Diptera communities within mango orchards of South Africa using pan traps at 100m, 200m and at the maximal distance possible from any natural habitat. We measured the response of insect abundance, wing span and body size as well as functional diversity to habitat isolation during mango flowering (dry season), and during the wet season (after mango fruit harvest). Flying insect abundance decreased with increasing distance to natural habitat during mango flowering, but no effect was detected during the wet season. FD of flying insects declined with increasing distance to natural habitat in both sampling periods. Insects captured during mango flowering were smaller but had 
51 higher wing length/body length ratios than those caught during the wet season. This study

52 highlights that mango orchards are more inhospitable for flying insects during mango

53 flowering. This effect might be due to low palatability of mango flowers, or pesticide use in

54 mango fields. In order to maintain a high FD of flower-visiting species, and reduce the

55 detrimental effects of habitat isolation to ultimately ensure better crop pollination, we propose

56 establishment of patches of resource-rich habitats combined with judicious use of pesticides

57 within orchards.

58

59 Keywords

60 Body size, Flower-visitors, Functional diversity, Isolation from natural habitat, Mangoes,

61 Morphological traits, Wing span

62 


\section{Introduction}

To ensure nutritional security to a burgeoning human population, the demand for animalpollinated crops is continually increasing (Eilers et al. 2011; Ehrlich and Harte, 2015). To meet this demand, agricultural production has intensified in recent decades through conversion of large areas to monocultures, with concomitant loss of natural and semi-natural areas, and increasing use of agrochemicals (Tscharntke et al. 2005; Kennedy et al. 2013). However, given the reported negative effects of agricultural intensification on pollinator populations (Kremen et al. 2002; Vanbergen et al. 2013), the benefits of intensification for animal-pollinated crop yield might be negated by ensuing pollinator loss (Garibaldi et al. 2011a; Leonhart et al. 2013; Deguines et al. 2014).By pollinating crops, insects provide a critical ecosystem service estimated to be worth more than $€ 153$ billion worldwide (Klein et al. 2003; Gallai et al. 2008; Winfree 2008). The decline of pollinators owing to agricultural intensification therefore raises concerns for food security (Aizen et al. 2008; Garibaldi et al. 2011a) and highlights the need for sustainable agriculture that ensures agricultural production whilst conserving biodiversity (Garibaldi et al. 2015, 2016).

In agricultural landscapes, natural areas provide habitat for wild insects and constitute sources of flower-visitors for crops (Kennedy et al. 2013; Morandin and Kremen, 2013). Many flower-visitors, such as bees, are central place foragers and usually visit plants close to their nests (Cresswell et al. 2000). As distant resources are more energetically costly to visit than proximate resources, it is predicted that flowers isolated from natural areas will be less frequently visited (Schmid-Hempel et al. 1985, 1986; Steffan-Dewenter and Tscharntke 1999). In croplands, species richness of flower-visitors, visitation rates, and pollination services all tend to decline with distance to natural areas (e.g. Ricketts et al. 2008; Carvalheiro et al. 2010; Garibaldi et al. 2011b). Whether or not flower-visitors disperse from natural habitats into the adjacent crop depends on many factors such as floral resource abundance, 
floral reward level or type of management (e.g., Kennedy et al. 2013). In this respect, pollinator functional traits can be key. Most studies on the effect of distance to natural patches of vegetation have not considered flower-visitor traits or their functional diversity (e.g. Ricketts et al. 2008; Farwig et al. 2009; Carvalheiro et al. 2010, 2012; Garibaldi et al. 2011b; but see Jauker et al. 2009; Williams et al. 2010; Benjamin et al. 2014). Yet traits such as flower-visitor body size are likely to affect pollination success as these traits can influence insect behaviour, foraging distances and pollen deposition (Hoehn et al. 2008). For example, foraging distance is primarily dictated by pollinator body size, and small flower-visitors will forage closer to their nests (Araújo et al. 2004; Greenleaf et al. 2007; Benjamin et al. 2014). Moreover, several studies have shown that functional diversity (FD) of flower-visitor communities enhances pollination by providing complementary pollination services, for example through niche partitioning of resource use in time and space (Fontaine et al. 2006; Hoehn et al. 2008; Albrecht et al. 2012; Fründ et al. 2013). Studying the effects of isolation from natural areas on traits and FD of flower-visitors can thus shed light on the factors which affect both crop pollination and the persistence of diverse flower-visitor communities in agroecosystems, informing effective land management strategies (Williams et al. 2010; Benjamin et al. 2014).

Temporal dynamics of agricultural landscapes are also important. Cultivated areas exhibit particularly large temporal variations in floral resources which could affect flower-visitor communities (Westphal et al. 2003). Mass flowering crops such as mangoes (Mangifera indica L., Anacardiaceae) constitute a super-abundant floral resource during a short period of time, representing a resource pulse for flower-visitors (Orford et al. 2015). The relationship between increasing distance to natural habitat and flower-visitor communities has been mostly explored during crop mass flowering (e.g. Holzschuh et al. 2011) but negative effects of distance on flower-visitors are likely to be stronger when the crop is not flowering, because 
113 only flowering weeds then provide resources in cultivated fields. Seasonal variation of wild

114 floral resources and flower-visitor communities also contribute to temporal variation of

115 agroecosystems. Spatiotemporal turnover in flower-visitor assemblages varies between and

116 within years in temperate and tropical ecosystems (Oertli et al. 2005; Rollin et al. 2015;

117 Samnegård et al. 2015), with temporal changes in abundance or even functional traits of

118 flower-visitors varying because of food and nesting requirements (Tylianakis et al. 2005;

119 Rollin et al. 2015). Flower-visitor assemblages might respond differently to agricultural

120 perturbations in different seasons (Samnegård et al. 2015). For example, in tropical

121 environments, resources are more scarce and patchily-distributed during the dry season

122 relative to the wet season. Greater mobility may therefore be advantageous to crop flower-

123 visitors during the dry season (see Samnegård et al. 2015).

124 To explore those questions, we studied the response of potential flower-visitors (hereafter

125 referred to as "flying insects") to increasing distance from natural vegetation in mango

126 orchards in north-eastern South-Africa in two different seasons. Mango is one of the most

127 important tropical fruits produced in the world, and is economically important for income and

128 employment-creation in the region (FAO, 2010). Research conducted in our study area in the

129 past has found clear effects of distance on pollination (Carvalheiro et al. 2010, 2012), pest

130 control (Henri et al. 2015) and bird assemblages (Ehlers Smith et al. 2015).

131 We used pan-traps to survey flying insects during mango flowering in the dry season (winter),

132 and during the wet season (summer, when mango is not flowering), along transects of

133 increasing distance to natural habitat. We hypothesised that the number of flying insects

134 caught in traps would decrease with distance to natural vegetation. If isolation from natural

135 areas is the only cause of the decrease in flying insect abundance, the effect should be

136 consistent between seasons. We also measured wing span and body length of each flying

137 insect and investigated distance effects on flower-visitor functional-trait diversity. We 
138 hypothesised a decline of the FD with increasing distance from natural areas in both seasons,

139 since species loss caused by isolation is likely to result in loss of trait diversity. Finally, given

140 links between size and flight abilities, we predicted that average insect body size would be

141 larger with increasing distance to natural area. 


\section{Materials and Methods}

\section{$143 \quad 2.1$ Study site}

144 Our study site was situated in the Kruger to Canyons Biosphere Region, Limpopo Province,

145 South Africa. This region includes agricultural areas and also two large protected areas

146 (Kruger National Park and Blyde River Canyon reserve; 24 24'S 3050'E). The entire area

147 retains more than $50 \%$ of intact vegetation unaffected by anthropogenic perturbations

148 (Coetzer et al. 2013).

149 Other than tourism, agriculture is an important source of employment in the area. Although in

150 some areas, there are small subsistence farms, in our study area, the farms are composed of

151 sets of large blocks of monoculture stands of mango, citrus or avocado. Mango farms

152 consisted of multiple plots of 0.66 to 3 ha (mean $\pm \mathrm{sd}=1.39 \pm 0.87$ ) separated by windbreaks

153 of tall Casuarina sp. trees. All the study farms provided similar water and nutrient supply and

154 made intensive use of herbicides (e.g., glycophosphates) and insecticides (neonicotinoids or

155 organophosphates). The sets of blocks of mango plantation are bordered by patches of natural

156 vegetation that vary in size, but are usually at least $250 \mathrm{~m}$ wide. These patches of natural

157 vegetation have not been ploughed, and differ from natural vegetation in neighbouring Kruger

158 National Park in that livestock have replaced wild herbivores. The vegetation in the area is

159 Granite Lowveld (Mucina and Rutherford, 2006), a savannah in which the woody component

160 is dominated by Acacia (Senegalia) nigrescens and Sclerocarya birrea, with a herbaceous

161 layer that includes Digitaria eriantha, Panicum maximum and Aristida congesta.

162 The primary flower-visitors to mango in this area include Diptera (mostly Calliphoridae and

163 Empididae families), and Hymenoptera (Apis mellifera, Ceratina spp. bees and species of

164 Campenotus, Monomorium and Tetramorium ants; Carvalheiro et al. 2010, 2012). Mango is

165 self-compatible, but only to a small extent: a bagging experiment found that there was $21 \%$

166 fruit set for inflorescences from which pollinators had been excluded (100\% of fruit set in 
open inflorescences see Carvalheiro et al. 2010). Mango flowers do produce nectar, but only a

168 small amount of pollen (Eardley et al. 2007).

169 The first surveys were performed during mango flowering (July-August 2013, dry season

170 hereafter), with maximum temperatures averaging around $26^{\circ} \mathrm{C}$ and minima of $9^{\circ} \mathrm{C}$. The lack

171 of rain during this time means that few flowering species are in bloom for flower-visiting

172 insects. We selected five mango farms separated from each other by between three to thirteen

173 kilometres. Within each farm, we established two transects perpendicular to the edge between

174 mango and natural vegetation. Along each transect, we sampled insects at 5 sampling points,

175 at $50 \mathrm{~m}$ from the edge with mango in the natural vegetation, at the field edge $(0 \mathrm{~m})$ and at 100 ,

$176200 \mathrm{~m}$ and the maximal distance possible from any natural habitat within mango orchards.

177 Distance to natural vegetation was measured as the distance from each set of traps within the

178 blocks of mango to the border of the nearest patch of natural vegetation. During April-May

1792014 , we re-sampled insects in two transects in each of the three most accessible farms. April-

180 May coincides with the end of the wet season, when maximum and minimum temperatures

181 average $29^{\circ} \mathrm{C}$ and $12^{\circ} \mathrm{C}$, respectively, and floral resources are fairly abundant, having

182 flourished during the rains.

183 At each sampling point, three coloured pan traps (radius $=7.25 \mathrm{~cm}$, depth $=5 \mathrm{~cm}$ ) painted with

184 UV-reflecting paints (yellow, blue and white) were placed and filled with $400 \mathrm{ml}$ of water and

185 a drop of detergent (surfactant). Although pan trap sampling is known to under-sample some

186 insect groups like large bees (Bombus, Colletes), this method is nevertheless considered the

187 most efficient method to sample flying flower-visitors (Roulston et al. 2007; Westphal et al.

188 2008, Nielsen et al. 2011). It allows sampling of a large number of points simultaneously and

189 uniformly, obtaining standardized estimates of flower visitor abundance and diversity. 
In dry and wet seasons, we performed three sampling sessions in each transect (one every two

193 weeks) where traps were set out in the field for 24 hours before being collected $(\mathrm{N}=720$ pan

194 traps). Traps were set on warm sunny days (minimum of $15^{\circ} \mathrm{C}$, no wind and clear sky). Once

195 collected, insects were stored in $70 \%$ ethanol before being rinsed, identified at the order level

196 and measured. We focused on potential pollinators including Hymenoptera, Lepidoptera and

197 Diptera, which are groups that are considered as mango pollinators (Sung et al. 2006).

198 Morphometric measures of insects were also taken, i.e. wing length (distance between the 199 wing tips) and body length using digital callipers (Digit-Cal MK IV 599-571, Brown and 200 Sharpe, USA, $0.01 \mathrm{~mm})$.

201 Finally, we assessed the number of mango flowers and wild flowers in a perimeter of 15 202 meters around each sampling point. Within mango orchards, the herbaceous cover was 203 dominated by non-native weeds (e.g. Tridax procumbens (L.) and Bidens pilosa (L.), both 204 Asteraceae). Since mangoes exhibit "big bang" flowering with a massive number of flowers 205 per tree, we estimated the number of mango flowers by counting the number of flowers on 206 three different panicles and multiplying the average by the number of panicles for each tree (a 207 mature tree has 600-1000 panicles; Manning, 1995; Sung et al. 2006).

\subsection{Functional Diversity}

210 Our dataset was comprised of individual insects, and not species, so we calculated functional 211 diversity of the individuals found in our samples. We used order, body length, wing span and 212 the ratio of body length to wing length as traits. Order was represented as a binary variable of 213 one or zero for each of three categories (Diptera, Hymenoptera or Lepidoptera), and therefore 214 order was represented by three "traits". We therefore down-weighted order to one third the 215 value of the other traits to avoid biasing the analysis. 
216 We calculated the FDis (Functional Dispersion, Laliberté and Legendre 2010) measure of

217 functional diversity, using the FD package in R (Laliberté et al. 2010). In this case, FDis is the 218 mean distance of individuals to the centroid calculated for all individuals in multidimensional 219 trait space. FDis is not affected by species richness (in our case, abundance), and is able to 220 handle missing values and qualitative as well as quantitative traits (Laliberté and Legendre $2212010)$.

\subsection{Data analysis}

224 We assessed how functional diversity and the value of each of the traits used to calculate 225 functional diversity (i.e. body length, wing length, and ratio of wing length over body length) 226 changed with season and habitat. Although functional diversity is a measure of the variation 227 in these traits, changes in the average values of traits yields insights into how the traits themselves are affected by habitat and season. These two analyses therefore produce complementary information.

We assessed the effects of sampling season (dry or wet season), habitat (natural vegetation or mango fields) and distance to natural habitat, as well as the interactions between season and 232 distance or habitat effects, on flower abundance, abundance and traits of flying insects and on flying insect functional diversity. To do so, for each response variable, we performed a model averaging approach which allows comparison of all possible submodels from a global model containing all the predictors of interest, in order to identify the best set of models describing

236 the observed variation (Grueber et al. 2011). With this approach, it is possible to account for 237 model uncertainty and to assess the relative importance of various predictor variables.

238 To analyse patterns in flower abundance, traits of flying insects and functional diversity FDis, 239 we used linear mixed-effect models on log-transformed response variables (except for FDis) 240 using distance to natural vegetation, sampling season, type of habitat, interactions between 
distance and sampling season, and interactions between type of habitat and sampling season

242 as fixed variables. Farm, transect nested within farm and date of sampling were included as

243 random effects to avoid pseudo-replication (Crawley, 2007). Additionally, in models with

244 insect traits as a response variable, we included insect order as a random effect to account for

245 differences in trait values between orders.

246 To assess variations in abundance of flying insects, we carried out generalized linear mixed-

247 effect models (GLMER) with a Poisson distribution and a log-link using the same fixed and

248 random variables with the addition of flower abundance as a fixed variable. We included

249 flower abundance as an explanatory variable because pan-traps are known to be less attractive

250 to flower-visitors in resource-rich sites relative to resource-poor sites (Wilson et al. 2008).

251 The GLMERs were corrected for overdispersion by including observation-level random

252 factors (Harrison 2014).

253 For each response variable, we selected the set of models according to the Akaike information

254 criterion (AIC). More precisely, we kept the models that were within the range of four highest

255 AIC units and we used these "top models" to estimate the mean effects and confidence

256 intervals of each predictor variable using model averaging (natural average method, Grueber

257 et al. 2011). We also measured the relative importance of each predictor variable which is

258 expressed as the relative sum of the Akaike weights across all top models in which the

259 variable appears (relative importance is equal to 1 for variables present in all top models).

260 Additionally, we calculated the marginal $\mathrm{R}^{2}$ values (fixed effects) and conditional $\mathrm{R}^{2}$ values

261 ( $\mathrm{R}^{2}$ both fixed and random effects) to assess the amount of variance explained by the best

262 model (i.e. with highest AIC; Johnson 2014). All analyses were performed using the R

263 statistical interface (v 3.1.0, R Development Core Team, 2014); mixed models were

264 conducted using the package lme4 (Bates et al. 2014) and model comparison and averaging

265 were performed with the functions dredge, get.models and model.avg (package MuMIn; 
Barton 2016). Model predictor variables were also centered and standardized with the

267 function standardize (package arm; Gelman and Su, 2015) to facilitate comparison between

268 the relative strengths of parameter estimates (Grueber et al. 2011). $\mathrm{R}^{2}$ values were calculated

269 with the function r.squared GLMM (package MuMIn; Barton 2016).

270

271 3. Results

\section{3.1. Abundance of flowers}

273 Distance to natural vegetation, as well as habitat type, sampling season and their interactions

274 (habitat×season and distancexseason), were included in all top models describing the response

275 of flower abundance (Table 1). As expected, the abundance of flowers was greater in mango

276 fields in the dry than in the wet season, whereas we observed more flowers in the nearby

277 natural vegetation during the wet season (see parameter estimate and confidence interval of

278 the interaction between sampling season and habitat type in Table 1, Figure 1A). Flower

279 abundance was far higher in the mango fields than in the natural vegetation during the dry

280 season (Figure 1A), given that we did not observe any flowers in the neighbouring natural

281 vegetation in any of the sampling sessions in the five farms over the dry season. The

282 abundance of flowers also increased with increasing distance from natural vegetation (Figure

283 1A). The interaction between distance and season had only $35 \%$ relative importance to other

284 predictor variables and the confidence interval for this parameter estimate included 0 . Thus

285 there was little evidence that the effect of distance from natural vegetation on flower

286 abundance differed between seasons.

$288 \quad 3.2$ Abundance of flying insects

289 Distance to natural vegetation, sampling season, and the interaction between these two

290 variables, were included in all top models describing the response of abundance of flying 
291 insects (Table 1). The abundance of flying insects was far higher during the wet season than

292 the dry season, which was expected since we captured 798 insects in the five farms during the 293 dry season but captured 1719 insects in only three of these farms during the wet season.

294 Abundance of flying insects declined with increasing distance from natural vegetation, but 295 only during the dry season (Table 1, Figure 1B). The difference in abundance of flying insects 296 between the two sampling periods was also more pronounced in mango fields (see parameter 297 estimate and confidence interval of the interaction between sampling season and habitat type 298 in Table 1), but there was weaker evidence for this effect (55\% relative importance). Lastly, 299 there was very little evidence of an effect of flower abundance on the abundance of flying 300 insects (39\% relative importance to distance and season, and the confidence interval for this 301 parameter estimate included 0).

302

\subsection{Functional diversity}

304 Distance to natural vegetation and sampling season were included in all top models describing 305 the response of functional diversity (Table 1). Functional diversity of flying insects was 306 higher in the wet season than during the dry season and FD declined with increasing distance 307 from natural vegetation in both seasons (Figure 1C). Functional diversity was also higher in 308 nearby natural vegetation than in mango fields (79\% relative importance to distance and

309 season, Table 1). The interaction between distance and season had only $23 \%$ relative 310 importance and the confidence interval for this parameter estimate included 0 . Thus, there was 311 little evidence that the negative effect of distance from natural vegetation on functional 312 diversity differed between seasons.

\section{4 Insect traits}


315 Only sampling season was included in all top models describing the responses of body length,

316 wing span and ratio of wing span to body length of flying insects (Table 2). Both body length

317 and wing span of flying insects were on average smaller during the dry than during the wet

318 season, whereas the ratio of wing span to body length was larger during the dry season

319 (Figure 2). Body length and wing span of flying insects also differed between habitat types,

320 insects being on average larger in natural vegetation than in mango fields (Figure 2, Table 2).

321 Although body length and wing span of flying insects tended to decrease with increasing

322 distance to natural vegetation during the dry season (Figure 2), this effect was not significant

323 (the confidence interval for the corresponding estimate included 0 ). There was very little

324 evidence of any effect of habitat type and distance to natural vegetation on the ratio of wing

325 span to body length of flying insects (Table 2). In addition, the marginal $\mathrm{R}^{2}$ of the models

326 were very low (about 0.02 , see Table 2), indicating that on average variance in insect traits

327 explained by effects of distance, habitat type and sampling season was only $2 \%$ whereas

328 random factors (which represented insect order, as well as sample position and date)

329 explained between 40 and $50 \%$ of the variation. 


\section{Discussion}

333 This study highlights that mango orchards are more inhospitable for flying insects during the

334 dry (mango flowering) than during the wet season, despite the abundance of mango flowers

335 available in the orchards. We found declines in insect abundance with increasing distance to

336 natural areas during the dry season whereas no pattern was found during the wet season. The

337 functional diversity (FD) of flying insects declined with increasing distance to natural habitat

338 in both sampling periods, however, and insects were on average smaller in mango orchards

339 than in natural vegetation. Taken together, our results suggest impacts on crop yield, given

340 that as a rule, rate of flower visitation (Vázquez et al. 2005, Garibaldi et al. 2013) and

341 functional diversity (Fontaine et al. 2006, Hoehn et al. 2008, Albrecht et al. 2012, Fründ et al.

342 2013) increase crop fruit set. Creating patches of habitat rich in native floral resources that

343 flower before and during mango flowering within orchards could mitigate the detrimental

344 effects of isolation from natural habitats and increase mango production (Carvalheiro et al.

345 2012).

\section{$347 \quad 4.1$ Seasonal variation in flying insect abundance}

348 Agricultural landscapes show strong temporal variation in the floral resource offer. Mass

349 flowering crops, during their flowering season, are expected to exert a strong magnet effect on

350 pollinators from adjacent areas (Blitzer et al. 2012). We did not find this effect, however, and

351 this was somewhat surprising, given that there are few other floral resources in the landscape

352 at this time. It is possible that this pulse of floral resources is too short-lived to enable

353 invertebrate populations to respond to this sudden availability in floral resources. This finding

354 highlights the importance of considering seasonal variation in the value of agricultural patches 355 for pollinators. 
The decline in insect abundance with increasing distance to natural vegetation that we

357 observed during the dry season is a pattern that has been observed in numerous studies in 358 agricultural systems (e.g. Ricketts et al. 2008; Garibaldi et al. 2011b). This pattern appears 359 stronger in tropical than temperate regions (Ricketts et al. 2008) and has been particularly 360 well documented by Carvalheiro et al. (2010) in our study system. This latter study notably 361 showed that even in a biodiversity rich area, with a high proportion of intact natural habitat, 362 the abundance of flying insects was impacted by isolation from natural habitats, which in turn 363 impacted crop fruit set. Because several flying insects such as bees are central place foragers

364 (i.e. individuals that return to their nests after foraging (for nectar and/or pollen; Williams and 365 Kremen, 2007), this decline in insect abundance with increasing distance to natural area is 366 commonly attributed to the distance from nesting sites and foraging resources available in 367 natural habitats (e.g. Ricketts et al. 2008; Farwig et al. 2009; Williams et al. 2010; Garibaldi 368 et al. 2011b; Samnegård et al. 2015).

369 But intriguingly, in complete contrast to the dry season when mango is flowering, we did not 370 observe any effect of distance to natural area on insect abundance during the wet season.

371 These contrasting results might be explained by the seasonal dynamics of wild floral 372 resources and pollinator communities. Flying insects were more abundant and had higher 373 functional diversity during the wet than dry season, which is expected since the wet season 374 coincides with spring/summer, when more floral resources are available and temperatures are 375 higher. The link between plant richness and abundance and flower-visitor richness and 376 abundance has been well documented in the scientific literature for croplands (e.g., Holzschuh 377 et al., 2007; Kennedy et al., 2013). The higher diversity of native flowering plant during the 378 wet season, and the increasing availability of weed flowers with increasing distance from 379 natural vegetation within mango orchards might explain the absence of a relationship between 380 isolation from natural habitat and insect abundance. It is also worth noting that mango flowers 
381

382

yield only small amounts of pollen, although they do offer some nectar (Eardley et al. 2007), and so are not very attractive to many insects (Free and Willams 1976). Thus, the lack of attractiveness of mango mass flowering might explain the strong negative effect of isolation from natural habitat we observed during the dry season. This idea is supported by an earlier study in which small planted patches of native flowering plants within mango orchards were associated with an increased abundance of flower-visitors to mango flowers, which mitigated to some extent the effects of isolation (Carvalheiro et al. 2012).

In addition to the limitations in floral resources, alternative explanations exist that might explain seasonal variation in distance effects on flying insects in the crop. Pesticides are used in mango fields, even during mango flowering. Many studies have reported on the negative effect of pesticides on flower-visitors (Henry et al. 2012; Goulson et al. 2015; Stanley et al. 2015), and Carvalheiro et al. (2012) also previously highlighted the detrimental effect of pesticide use on flying insect along gradients of increasing distance to natural area in our study system. Varying pesticide applications might thus also explain the different effects of distance to natural area on insect abundance between the two sampling seasons.

Pan-traps are widely considered to provide accurate surveys of bee assemblages (Roulston et al. 2007, Westphal et al. 2008, Geslin et al. 2016), but are also prone to some bias. Pan-traps under-sample large insects and their attractiveness can vary with the amount of flowers locally present (Wilson et al. 2008, Popic et al. 2013). The relative attractiveness of pan-traps decreases as floral resources increase because pan traps compete with flowers for flying insect attention. However, it is unlikely that our results are an artefact of pan-trapping. We included floral abundance as an explanatory variable in our statistical models, and this variable did not have a significant effect on insect abundance. Secondly, in both seasons, more flowers were observed in mango orchards compared to natural habitats and the decline in insect abundance 
with increasing distance to natural habitat was observed uniquely during the dry season, with

406 the same capture method.

407

\subsection{Functional diversity}

409 Although flying insect abundance decreased with increasing distance from natural habitat

410 during the dry season only, declines in functional diversity with increasing isolation were

411 consistent in the two sampling seasons. A recent study highlighted that farmed landscapes

412 were detrimental to the maintenance of functional-trait diversity of flying insects (Forrest et

413 al. 2015), and our findings support this view.

414 FD is increasingly recognized as being more important than species diversity to ecosystem

415 functioning (Gagic et al. 2015) and has been suggested to be the major component of diversity

416 (Tilman et al. 1997; Hulot et al. 2000; Hoehn et al. 2008). The main reason for the importance

417 of FD lies in the complementarity of pollination services through niche partitioning of

418 resource use in time and space (Fontaine et al. 2006; Hoehn et al. 2008; Albrecht et al. 2012;

419 Fründ et al. 2013). The value of greater FD to pollination services has been demonstrated both

420 experimentally (Fontaine et al. 2006) and empirically (Hoehn et al. 2008), and a recent

421 example in apple orchards highlighted that fruit and seed set was mainly mediated by bee FD

422 (Martins et al. 2015, but see Garibaldi et al. 2015).

423 The loss of FD with increasing isolation can reduce the efficiency of pollination (Forrest et al.

424 2015; Wood et al. 2015) reducing yield for trees at the centre of mango orchards. Carvalheiro

425 et al. (2010, 2012), demonstrated that agricultural production and proximity to natural habitat

426 are positively correlated in the mango orchards we studied. Yet, easily implementable

427 management practices might ameliorate, to some extent, the negative effects of isolation.

428 Creating patches of flowering rich habitat has been shown to increase crop yield in mango

429 orchards (Carvalheiro et al. 2012). FD of flying insects has been shown to improve with only 
modest enhancements of floral diversity (Orford et al. 2016). Given that isolation from natural

431 habitat together with loss of flower-visitor abundance and diversity are now well established

432 as critical drivers of limitation in crop yield (Garibaldi et al. 2016), we encourage the

433 establishment of those simple management practices to enhance food production.

\subsection{Traits of flying insects}

436 In contrast to functional diversity, there was weak evidence of distance effects on average 437 insect trait values, and the traits were only weakly affected by habitat type. Although a large 438 part of the variance in insect traits was related to size differences between orders, sampling 439 season had also a significant effect on flying insect average body length and wing span.

440 During the dry season in tropical environments, resources are scarcer and more patchily441 distributed compared to the wet season (Samnegård et al. 2015). Because the foraging range 442 of flying insects is positively correlated with their body size (Araújo et al. 2004; Greenleaf et 443 al. 2007), we initially hypothesized that we would trap larger flying insect during the dry 444 season. However, our results show that insects were smaller during the dry season. This 445 finding is more consistent with the findings of Wray et al. (2014), who found large-bodied 446 species to be favoured by increasing availability of floral resources (although this was in a 447 landscape context of urbanisation). Indeed, large-bodied species may have larger resource 448 needs and smaller population sizes (Kremen and McGonigle, 2015), which could 449 disadvantage them during the dry season. We nevertheless did detect a greater ratio of wing to 450 body length during the dry season, which might indicate greater mobility of insects relative to 451 their size than during the wet season. Insect size differences between seasons might also arise 452 from differences in climatic conditions such as temperature. Some studies reported that higher 453 wing to thorax size ratios could be selectively advantageous at lower temperatures (e.g., 454 Azevedo et al. 1998), which is in agreement with what we found during the dry/winter season. 
Species turnover between seasons likely explains the difference in insect sizes between

456 seasons. The distribution of insect body size/tongue size has been found to closely match the

457 distribution of flower corolla tube depth (Agosta and Janzen 2005, Stang et al. 2006; 2009)

458 and to determine the abundance of interactions in pollinator webs (Stang et al. 2006, Geslin et

459 al. 2013). The distribution of the size of insects might be due to the predominance of flowers

460 with short corollas during the dry season because mango flowers, as well as the dominant

461 non-native weeds T. procumbens and B. pilosa have short corollas. This is supported by the

462 fact that the few large individuals of flying insect we found during the dry season were

463 trapped in natural habitat where plants such as Grewia spp., have flowers that present a more

464 tubular and deep corolla structure. Finally, we observed larger insects, in both seasons, in the

465 natural vegetation compared to mango orchards. Some studies have found large-bodied flying

466 insects to be more prone to extinction in response to land use intensity and habitat loss

467 (Larsen et al. 2005, Bartomeus et al. 2013; Rader et al 2014), whereas others have found non-

468 significant effects (Williams et al. 2010), and several authors found small insects to be more

469 negatively affected by isolation and habitat loss than larger ones (Bommarco et al. 2010;

470 Öckinger et al. 2010; Jauker et al. 2013). Here, large-bodied species seemed more sensitive to

471 agricultural perturbations than small bodied ones and were thus less abundant in mango

472 orchards. Moreover, flowers within mango orchards may be less attractive to large bodied

473 insects because of the nectar and pollen offerings of mango flowers relative to wild flower

474 species.

475

\section{5. Conclusion}

477 Our study provides new evidence of the detrimental effects of isolation from natural habitats,

478 even in a biodiversity rich area, on abundance and functional diversity of flying insects in

479 different seasons. Although these deleterious effects were season-dependent for insect 
480 abundance (i.e. negative effects of distance from natural vegetation only during crop

481 flowering), functional diversity declined consistently with increasing distance from natural

482 habitat in both dry and wet seasons. This study thus sheds a light on the importance of

483 providing patches of resource-rich habitat within orchards over the year to mitigate the

484 detrimental effects of isolation and maintain functionally-diverse insect communities. Such

485 management practices are easily achievable in mango orchards and should be encouraged.

486 Finally, this study also underlines the temporal variability within a year of patch use by flying

487 insect communities within an agricultural landscape. Agricultural landscapes and mechanisms

488 that structure flying insect communities should thus be studied at various spatial and temporal

489 scales. We encourage new studies regarding links between morphological traits of insects and

490 agricultural intensification, contributing to a synthesis that can untangle the relative

491 importance of temporal and spatial contexts, crop and management practices. 


\section{Acknowledgments}

494 We are grateful to Floriane Flacher, Lavhelesani Simba, Lyndre Nel, Anne-Sophie Bonnet-

495 Lebrun, Pierre Quévreux, Thomas Aubier and Kejun Zou for their help with data collection.

496 BG thanks Lucas A. Garibaldi and Boris Leroy for useful discussions. This work was

497 supported by the European Commission Marie Curie International Research Staff Exchange

498 Scheme (IRSES) ('NETWORK' project, Grant agreement: PIRSES-GA-2012-318929). . 


\section{References}

500 Agosta, S.J., Janzen, D.H., 2005. Body size distributions of large Costa Rican dry forest moths and the underlying relationship between plant and pollinator morphology. Oikos 108, 183-193. doi:10.1111/j.0030-1299.2005.13504.x

503

504

505

506

Aizen, M. A., Garibaldi, L.A., Cunningham, S. A., Klein, A.M., 2008. Long-term global trends in crop yield and production reveal no current pollination shortage but increasing pollinator dependency. Curr. Biol. 18, 1572-5. doi:10.1016/j.cub.2008.08.066

Albrecht, M., Schmid, B., Hautier, Y., Müller, C.B., 2012. Diverse pollinator communities enhance plant reproductive success. Proc. Biol. Sci. 279, 4845-52. doi:10.1098/rspb.2012.1621

Araújo, E., Costa, M., 2004. Body size and flight distance in stingless bees (Hymenoptera: Meliponini): inference of flight range and possible ecological implications. Brazilian J. Biol. 64, 563-568.

Azevedo, Ricardo BR, Avis C. James, Jennie McCabe, and L. Partridge. 1998. Latitudinal variation of wing: thorax size ratio and wing-aspect ratio in Drosophila melanogaster. Evolution 5: 1353-1362.

Bartomeus, I., Park, M.G., Gibbs, J., Danforth, B.N., Lakso, A.N., Winfree, R., 2013. Biodiversity ensures plant-pollinator phenological synchrony against climate change. Ecol. Lett. 16, 1331-8. doi:10.1111/ele.12170

Barton K., 2016. MuMIn: Multi-Model Inference. R package version 1.15.6. https://CRAN.Rproject.org/package $=$ MuMIn

Bates, D., M. Maechler, B. Bolker, and S. Walker., 2014. lme4:Linear mixed-effects models using Eigen and S4. R package version 1.1-5. 
Benjamin, F., R. Reilly, J., Winfree, R., 2014. Pollinator body size mediates the scale at which land use drives crop pollination services. J. Appl. Ecol. 51, 440-449. doi:10.1111/1365-2664.12198

Blitzer, E.J., Dormann, C.F., Holzschuh, A., Klein, A.M., Rand, T.A., Tscharntke, T., 2012. Spillover of functionally important organisms between managed and natural habitats. Agric. Ecosyst. Environ. 146, 34-43. doi:10.1016/j.agee.2011.09.005

Bommarco, R., Biesmeijer, J.C., Meyer, B., Potts, S.G., Pöyry, J., Roberts, S.P.M., SteffanDewenter, I., Ockinger, E., 2010. Dispersal capacity and diet breadth modify the response of wild bees to habitat loss. Proc. Biol. Sci. 277, 2075-2082. doi:10.1098/rspb.2009.2221

Carvalheiro, L.G., Seymour, C.L., Veldtman, R., Nicolson, S.W., 2010. Pollination services decline with distance from natural habitat even in biodiversity-rich areas. J. Appl. Ecol. 47, 810-820. doi:10.1111/j.1365-2664.2010.01829.x

Carvalheiro, L.G., Seymour, C.L., Nicolson, S.W., Veldtman, R., 2012. Creating patches of native flowers facilitates crop pollination in large agricultural fields: mango as a case study. J. Appl. Ecol. 49, 1373-1383. doi:10.1111/j.1365-2664.2012.02217.x

Coetzer, K.L., Erasmus, B.F.N., Witkowski, E.T.F., Reyers, B., 2013. The race for space: Tracking land-cover transformation in a socio-ecological landscape, South Africa. Environ. Manage. 52, 595-611. doi:10.1007/s00267-013-0094-9

Crawley, M. (2007). The R book. John Wiley and Sons Ltd., Chichester, UK, 949 pp.

Cresswell, J.E., 2000. A comparison of bumblebees' movements in uniform and aggregated distributions of their forage plant. Ecol. Entomol. 25, 19-25. doi:10.1046/j.13652311.2000.00230.x 
Deguines, N., Jono, C., Baude, M., Henry, M., Julliard, R., Fontaine, C., 2014. Large-scale trade-off between agricultural intensification and crop pollination services. Front. Ecol. Environ. 12, 212-217. doi:10.1890/130054

Eardley, C., B. Gemmill-Herren, M. Gikungu, R. Kagioya, W. Kinuthia, P. K. Kwapong, D. Mar-tins, L. Njoroge, and G. Tribe. 2007. Crops, browse and pollinators in Africa: an initial stock-taking. FAO, Rome.

Eilers, E.J., Kremen, C., Smith Greenleaf, S., Garber, A.K., Klein, A.-M., 2011. Contribution of pollinator-mediated crops to nutrients in the human food supply. PLoS One 6, e21363. doi:10.1371/journal.pone.0021363

Ehlers Smith, Y.C., Ehlers Smith, D.A., Seymour, C.L., Thébault, E., van Veen, F.J.F., 2015. Response of avian diversity to habitat modification can be predicted from life-history traits and ecological attributes. Landsc. Ecol. 30, 1225-1239. doi:10.1007/s 10980-0150172-x

Ehrlich, P.R., Harte, J., 2015. Opinion: To feed the world in 2050 will require a global revolution. PNAS 112, 14743-14744. doi:10.1073/pnas.1519841112

Farwig, N., Bailey, D., Bochud, E., Herrmann, J.D., Kindler, E., Reusser, N., Schüepp, C., Schmidt-Entling, M.H., 2009. Isolation from forest reduces pollination, seed predation and insect scavenging in Swiss farmland. Landsc. Ecol. 24, 919-927. doi:10.1007/s10980-009-9376-2

Forrest, J.R.K., Thorp, R.W., Kremen, C., Williams, N.M., 2015. Contrasting patterns in species and functional-trait diversity of bees in an agricultural landscape. J. Appl. Ecol. 52, 706-715. doi:10.1111/1365-2664.12433

Free, J.B., Williams, I.H. 1976. Insect pollination of Anacardium occidentale L., Mangifera indica L., Blighia sapida Koenig and Persea americana Mill. Tropical Agriculture, 53, $125-139$. 
Fründ, J., Zieger, S.L., Tscharntke, T., 2013. Response diversity of wild bees to overwintering temperatures. Oecologia 173, 1639-1648. doi:10.1007/s00442-013-2729-1

Fontaine, C., Dajoz, I., Meriguet, J., Loreau, M., 2006. Functional diversity of plant-pollinator interaction webs enhances the persistence of plant communities. PLoS Biol. 4, e1. doi:10.1371/journal.pbio.0040001

Gagic, V., Bartomeus, I., Jonsson, T., Taylor, A., Winqvist, C., Fischer, C., Slade, E.M., Steffan-dewenter, I., Emmerson, M., Potts, S.G., Tscharntke, T., Weisser, W., Bommarco, R., 2015. Functional identity and diversity of animals predict ecosystem functioning better than species-based indices. doi:http://dx.doi.org/10.1098/rspb.2014.2620

Gallai, N., Salles, J.-M., Settele, J., Vaissière, B.E., 2008. Economic valuation of the vulnerability of world agriculture confronted with pollinator decline. Ecol. Econ. 68, 810-821. doi:10.1016/j.ecolecon.2008.06.014

Garibaldi, L. A, Aizen, M. A, Klein, A.M., Cunningham, S. a, Harder, L.D., 2011a. Global growth and stability of agricultural yield decrease with pollinator dependence. Proc. Natl. Acad. Sci. U. S. A. 108, 5909-5914. doi:10.1073/pnas.1012431108

Garibaldi, L. A, Steffan-Dewenter, I., Kremen, C., Morales, J.M., Bommarco, R., Cunningham, S. A, Carvalheiro, L.G., Chacoff, N.P., Dudenhöffer, J.H., Greenleaf, S.S., Holzschuh, A., Isaacs, R., Krewenka, K., Mandelik, Y., Mayfield, M.M., Morandin, L. A, Potts, S.G., Ricketts, T.H., Szentgyörgyi, H., Viana, B.F., Westphal, C., Winfree, R., Klein, A.M., 2011b. Stability of pollination services decreases with isolation from natural areas despite honey bee visits. Ecol. Lett. 14, 1062-72. doi:10.1111/j.14610248.2011.01669.x

Garibaldi, L. a, Steffan-Dewenter, I., Winfree, R., Aizen, M. a, Bommarco, R., Cunningham, S. A, Kremen, C., Carvalheiro, L.G., Harder, L.D., Afik, O., Bartomeus, I., Benjamin, F., 
Boreux, V., Cariveau, D., Chacoff, N.P., Dudenhöffer, J.H., Freitas, B.M., Ghazoul, J., Greenleaf, S., Hipólito, J., Holzschuh, A., Howlett, B., Isaacs, R., Javorek, S.K., Kennedy, C.M., Krewenka, K.M., Krishnan, S., Mandelik, Y., Mayfield, M.M., Motzke, I., Munyuli, T., Nault, B. a, Otieno, M., Petersen, J., Pisanty, G., Potts, S.G., Rader, R., Ricketts, T.H., Rundlöf, M., Seymour, C.L., Schüepp, C., Szentgyörgyi, H., Taki, H., Tscharntke, T., Vergara, C.H., Viana, B.F., Wanger, T.C., Westphal, C., Williams, N., Klein, A.M., 2013. Wild pollinators enhance fruit set of crops regardless of honey bee abundance. Science 339, 1608-11. doi:10.1126/science.1230200

Garibaldi, L.A., Carvalheiro, L.G., Vaissiere, B.E., Gemmill-Herren, B., Hipolito, J., Freitas, B.M., Ngo, H.T., Azzu, N., Saez, A., Astrom, J., An, J., Blochtein, B., Buchori, D., Garcia, F.J.C., Oliveira da Silva, F., Devkota, K., Ribeiro, M. d. F., Freitas, L., Gaglianone, M.C., Goss, M., Irshad, M., Kasina, M., Filho, A.J.S.P., Kiill, L.H.P., A., Boreux, V., Garratt, M.P.D., Carvalheiro, L.G., Kremen, C., Morales, C.L., Schüepp, C., Chacoff, N.P., Freitas, B.M., Gagic, V., Holzschuh, A., Klatt, B.K., Krewenka, K.M., Krishnan, S., Mayfield, M.M., Motzke, I., Otieno, M., Petersen, J., Potts, S.G., Ricketts, T.H., Rundlöf, M., Sciligo, A., Sinu, P.A., Steffan-Dewenter, I., Taki, H., Tscharntke, T., Vergara, C.H., Viana, B.F., Woyciechowski, M., 2015. Trait matching of flower visitors and crops predicts fruit set better than trait diversity. J. Appl. Ecol. 52, 1436-1444. doi:10.1111/1365-2664.12530

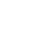


Gelman A., Su Y-S., 2015. arm: Data Analysis Using Regression and Multilevel/ Hierarchical Models. R package version 1.8-6. https://CRAN.R-project.org/package=arm

Geslin, B., Gauzens, B., Thébault, E., Dajoz, I., 2013. Plant Pollinator Networks along a Gradient of Urbanisation. PLoS One 8, e63421. doi:10.1371/journal.pone.0063421

Geslin, B., Le Féon, V., Kuhlmann, M., Vaissière, B.E., Dajoz, I., 2016. The bee fauna of large parks in downtown Paris, France. Ann. la Société Entomol. Fr. doi:10.1080/00379271.2016.1146632Greenleaf, S.S., Williams, N.M., Winfree, R., Kremen, C., 2007. Bee foraging ranges and their relationship to body size. Oecologia

Goulson, D., Nicholls, E., Botias, C., Rotheray, E.L., 2015. Bee declines driven by combined 153, 589-596. doi:10.1007/s00442-007-0752-9

stress from parasites, pesticides, and lack of flowers. Science (80-. ). 347, 12559571255957. doi:10.1126/science. 1255957

Grueber, C.E., Nakagawa, S., Laws, R.J. \& Jamieson, I.G., 2011 Multi- model inference in ecology and evolution: challenges and solutions. J. of Evo. Biol., 24, 699-711

Henri, D.C., Jones, O., Tsiattalos, A., Thébault, E., Seymour, C.L., van Veen, F.J.F., 2015. Natural vegetation benefits synergistic control of the three main insect and pathogen pests of a fruit crop in southern Africa. J. Appl. Ecol. 52, 1092-1101. doi:10.1111/13652664.12465

Henry, M., Béguin, M., Requier, F., Rollin, O., Odoux, J.-F., Aupinel, P., Aptel, J., Tchamitchian, S., Decourtye, A., 2012. A common pesticide decreases foraging success and survival in honey bees. Science 336, 348-50. doi:10.1126/science.1215039

Hoehn, P., Tscharntke, T., Tylianakis, J.M., Steffan-Dewenter, I., 2008. Functional group diversity of bee pollinators increases crop yield. Proc. Biol. Sci. 275, 2283-91. doi:10.1098/rspb.2008.0405 
643 Holzschuh, A., Steffan-dewenter, I., Kleijn, D., Tscharntke, T., 2007. Diversity of flower-

644 visiting bees in cereal fields : effects of farming system, landscape composition and 645 regional context 41-49. doi:10.1111/j.1365-2664.2006.01259.x

646 Holzschuh, A., Dormann, C.F., Tscharntke, T., Steffan-Dewenter, I., 2011. Expansion of 647 mass-flowering crops leads to transient pollinator dilution and reduced wild plant 648 pollination. Proc. Biol. Sci. 278, 3444-51. doi:10.1098/rspb.2011.0268

649 Hulot, F. D., Lacroix, G., Lescher-Moutoué, F. \& Loreau, M., 2000 Functional diversity 650 governs response to nutrient enrichment. Nature, 405, 340-344.

651 Jauker, F., Diekötter, T., Schwarzbach, F., Wolters, V., 2009. Pollinator dispersal in an 652 agricultural matrix: opposing responses of wild bees and hoverflies to landscape 653 structure and distance from main habitat. Landsc. Ecol. 24, 547-555. doi:10.1007/s10980-009-9331-2

Johnson, P.C.D., 2014. Extension of Nakagawa \& Schielzeth's R 2 GLMM to random slopes 656 models. Methods Ecol. Evol. 5, 944-946. doi:10.1111/2041-210X.12225

657 Kennedy, C.M., Lonsdorf, E., Neel, M.C., Williams, N.M., Ricketts, T.H., Winfree, R., 658 Bommarco, R., Brittain, C., Burley, A.L., Cariveau, D., Carvalheiro, L.G., Chacoff, N.P., 659 Cunningham, S.A., Danforth, B.N., Dudenhöffer, J.-H., Elle, E., Gaines, H.R., Garibaldi, 660 L.A., Gratton, C., Holzschuh, A., Isaacs, R., Javorek, S.K., Jha, S., Klein, A.M., 661 Krewenka, K., Mandelik, Y., Mayfield, M.M., Morandin, L., Neame, L.A., Otieno, M., 662 Park, M., Potts, S.G., Rundlöf, M., Saez, A., Steffan-Dewenter, I., Taki, H., Viana, B.F., 663 Westphal, C., Wilson, J.K., Greenleaf, S.S., Kremen, C., 2013. A global quantitative 664 synthesis of local and landscape effects on wild bee pollinators in agroecosystems. Ecol. 
Klein, A.-M., Steffan-Dewenter, I., Tscharntke, T., 2003. Fruit set of highland coffee increases with the diversity of pollinating bees. Proc. Biol. Sci. 270, 955-61. doi:10.1098/rspb.2002.2306

Klein, A.-M., Vaissière, B.E., Cane, J.H., Steffan-Dewenter, I., Cunningham, S. A, Kremen, C., Tscharntke, T., 2007. Importance of pollinators in changing landscapes for world crops. Proc. Biol. Sci. 274, 303-13. doi:10.1098/rspb.2006.3721

Kremen, C., M’Gonigle, L.K., 2015. Small-scale restoration in intensive agricultural landscapes supports more specialized and less mobile pollinator species. J. Appl. Ecol. n/a-n/a. doi:10.1111/1365-2664.12418

Kremen, C., Williams, N.M., Thorp, R.W., 2002. Crop pollination from native bees at risk from agricultural intensification. Proc. Natl. Acad. Sci. U. S. A. 99, 16812-16816. doi:10.1073/pnas.262413599

Laliberté, E., Legendre. P. 2010. A distance-based framework for measuring functional diversity from multiple traits. Ecology 91: 299-305

Laliberté, E., Legendre, P., Bill Shipley, 2010. Measuring functional diversity (FD) from multiple traits, and other tools for functional ecology. http://cran.rproject.org/web/packages/FD/FD.pdf

Larsen, T.H., Williams, N.M., Kremen, C., 2005. Extinction order and altered community structure rapidly disrupt ecosystem functioning. Ecol. Lett. 8, 538-547. doi:10.1111/j.1461-0248.2005.00749.x

Leonhardt, S.D.S., Gallai, N., Garibaldi, L.A., Kuhlmann, M., Klein, A.-M., 2013. Economic gain, stability of pollination and bee diversity decrease from southern to northern Europe. Basic Appl. Ecol. 14, 461-471. doi:10.1016/j.baae.2013.06.003

Manning, R. 1995. Honeybee pollination technical data. Western Australia Department of Agriculture, Bulletin No. 4298 
Martins, K.T., Gonzalez, A., Lechowicz, M.J., 2015. Pollination services are mediated by bee functional diversity and landscape context. Agric. Ecosyst. Environ. 200, 12-20. doi:10.1016/j.agee.2014.10.018

Morandin, L. A., Kremen, C., 2013. Hedgerow restoration promotes pollinator populations and exports native bees to adjacent fields. Ecol. Appl. 23, 829-839. doi:10.1890/121051.1

Mucina L., Rutherford M. C., 2006, The vegetation of South Africa, Lesotho and Swaziland Strelitzia 19. South African National Biodiversity Institute, Pretoria. 807pp.

Nielsen, A., Steffan-Dewenter, I., Westphal, C., Messinger, O., Potts, S.G., Roberts, S.P.M., Settele, J., Szentgyörgyi, H., Vaissière, B.E., Vaitis, M., Woyciechowski, M., Bazos, I., Biesmeijer, J.C., Bommarco, R., Kunin, W.E., Tscheulin, T., Lamborn, E., Petanidou, T., 2011. Assessing bee species richness in two Mediterranean communities: Importance of habitat type and sampling techniques. Ecol. Res. 26, 969-983. doi:10.1007/s11284-0110852-1

Öckinger, E., Schweiger, O., Crist, T.O., Debinski, D.M., Krauss, J., Kuussaari, M., Petersen, J.D., Pöyry, J., Settele, J., Summerville, K.S., Bommarco, R., 2010. Life-history traits predict species responses to habitat area and isolation: a cross-continental synthesis. Ecol. Lett. 13, no-no. doi:10.1111/j.1461-0248.2010.01487.x

Ollerton, J., Winfree, R., Tarrant, S., 2011. How many flowering plants are pollinated by animals? Oikos 120, 321-326. doi:10.1111/j.1600-0706.2010.18644.x

Oertli, S., Müller, A., Dorn, S., 2005. Ecological and seasonal patterns in the diversity of a species-rich bee assemblage (Hymenoptera: Apoidea: Apiformes. Eur. J. Entomol. 102, 53-63. doi:10.1016/j.biocon.2005.05.014 
714 Orford, K.A., Vaughan, I.P., Memmott, J., 2015. The forgotten flies: the importance of non$715 \quad$ syrphid Diptera as pollinators. Proc. Biol. Sci. 282, 20142934-.

$716 \quad$ doi:10.1098/rspb.2014.2934

717 Orford, K.A., Murray, P.J., Vaughan, I.P., Memmott, J., 2016. Modest enhancements to 718 conventional grassland diversity improve the provision of pollination services. J. Appl. $719 \quad$ Ecol. Online Only doi:10.1111/1365-2664.12608

720 Popic, T.J., Davila, Y.C., Wardle, G.M., 2013. Evaluation of common methods for sampling invertebrate pollinator assemblages: net sampling out-perform pan traps. PLoS One 8, e66665. doi:10.1371/journal.pone.0066665

R Development Core Team, 2014. R: A language and environment for statistical computing. R Foundation for Statistical Computing, Vienna, Austria. URL: http://www.r-project.org.

Rader, R., Bartomeus, I., Tylianakis, J.M., Laliberté, E., 2014. The winners and losers of land use intensification: pollinator community disassembly is non-random and alters functional diversity. Divers. Distrib. 20, 908-917. doi:10.1111/ddi.12221

Ricketts, T.H., Regetz, J., Steffan-Dewenter, I., Cunningham, S. A, Kremen, C., Bogdanski, A., Gemmill-Herren, B., Greenleaf, S.S., Klein, A.M., Mayfield, M.M., Morandin, L. A, Ochieng', A., Potts, S.G., Viana, B.F., 2008. Landscape effects on crop pollination services: are there general patterns? Ecol. Lett. 11, 499-515. doi:10.1111/j.14610248.2008.01157.x

Rollin, O., Bretagnolle, V., Fortel, L., Guilbaud, L., Henry, M., 2015. Habitat, spatial and temporal drivers of diversity patterns in a wild bee assemblage. Biodivers. Conserv. doi:10.1007/s10531-014-0852-X

Roulston, T.H., Smith, S.A., Brewster, A.L., Farm, B.E., Lane, B.F., 2007. A Comparison of Pan Trap and Intensive Net Sampling Techniques for Documenting a Bee (Hymenoptera : Apiformes) J. Kansas Entomol. Soc. 80, 179-181. 
Samnegård, U., Hambäck, P. A, Eardley, C., Nemomissa, S., Hylander, K., 2015. Turnover in bee species composition and functional trait distributions between seasons in a tropical agricultural landscape. Agric. Ecosyst. Environ. 211, 185-194. doi:10.1016/j.agee.2015.06.010

Schmid-Hempel, P., Kacelnik, A., Houston, A.I., 1985. Honeybees maximize efficiency by not filling their crop. Behav. Ecol. Sociobiol. 17, 61-66. doi:10.1007/BF00299430

Schmid-Hempel, P., \& Schmid-Hempel, R., 1986. Nectar-collecting bees use distancesensitive movement rules. Animal behaviour, 34, 605-607. doi:10.1016/S0003$3472(86) 80131-2$

Stang, M., Klinkhamer, P.G.L., Waser, N.M., Stang, I., van der Meijden, E., 2009. Sizespecific interaction patterns and size matching in a plant-pollinator interaction web. Ann. Bot. 103, 1459-1469. doi:10.1093/aob/mcp027

Stang, M., Klinkhamer, P.G.L., Van Der Meijden, E., 2006. Size constraints and flower abundance determine the number of interactions in a plant-flower visitor web. Oikos 112, 111-121. doi:10.1111/j.0030-1299.2006.14199.x

Stanley, D.A., Garratt, M.P.D., Wickens, J.B., Wickens, V.J., Potts, S.G., Raine, N.E., 2015. Neonicotinoid pesticide exposure impairs crop pollination services provided by bumblebees. Nature 528, 548-550. doi:10.1038/nature16167

Steffan-Dewenter, I., Tscharntke, T., 1999. Effects of habitat isolation on pollinator communities and seed set. Oecologia 121, 432-440.

Sung, I., Lin, M., Chang, C., Cheng, A., Chen, W., 2006. Pollinators and Their Behaviors on Mango Flowers in Southern Taiwan. Formos. Entomol. 170, 161-170.

Tilman, D., Knops, J., Wedin, D., Reich, P., Ritchie, M., Siemann, E., 1997. The influence of functional diversity and composition on ecosystem processes. Science. 277, 1300-1302. doi:10.1126/science.277.5330.1300 
Tscharntke, T., Klein, A.M., Kruess, A., Steffan-Dewenter, I., Thies, C., 2005. Landscape perspectives on agricultural intensification and biodiversity - Ecosystem service management. Ecol. Lett. doi:10.1111/j.1461-0248.2005.00782.x

Tylianakis, J.M., Klein, A.M., Tscharntke, T., 2005. Spatiotemporal variation in the diversity of hymenoptera across a tropical habitat gradient. Ecology 86, 3296-3302. doi:10.1890/05-0371

Vanbergen, A.J., and the Pollinator Initiative, 2013. Threats to an ecosystem service: pressures on pollinators. Front. Ecol. Environ. 11, 251-259. doi:10.1890/120126

Vázquez, D.P., Morris, W.F., Jordano, P., 2005. Interaction frequency as a surrogate for the total effect of animal mutualists on plants. Ecol. Lett. 8, 1088-1094. doi:10.1111/j.14610248.2005.00810.x

Westphal, C., Steffan-Dewenter, I., Tscharntke, T., 2003. Mass flowering crops enhance pollinator densities at a landscape scale. Ecol. Lett. 6, 961-965. doi:10.1046/j.14610248.2003.00523.x

Westphal, C., Bommarco, R., Carré, G., Lamborn, E., Morison, N., Petanidou, T., Potts, S.G., Roberts, S.P.M., Szentgyörgyi, H., Tscheulin, T., Vaissière, B.E., Woyciechowski, M., Biesmeuer, J.C., Kunin, W.E., Settele, J., Steffan-Dewenter, I., 2008. Measuring bee diversity in different European habitats and biogeographical regions. Ecol. Monogr. 78, 653-671. doi:10.1890/07-1292.1

Winfree, R., 2008. Pollinator-dependent crops: an increasingly risky business. Curr. Biol. 18, R968-9. doi:10.1016/j.cub.2008.09.010

Williams, N.M., Crone, E.E., Roulston, T.H., Minckley, R.L., Packer, L., Potts, S.G., 2010. Ecological and life-history traits predict bee species responses to environmental disturbances. Biol. Conserv. 143, 2280-2291. doi:10.1016/j.biocon.2010.03.024 
788 Williams, N.M., Kremen, C., 2007. Resource distributions among habitats determine solitary

789 bee offspring production in a mosaic landscape. Ecol. Appl. 17, 910-921.

$790 \quad$ doi:10.1890/06-0269

791 Wilson, J.S., Griswold, T., Messinger, O.J., 2008. Sampling Bee Communities

792 (Hymenoptera : Apiformes) in a Desert Landscape : Are Pan Traps Sufficient? J. Kansas

$793 \quad$ Entomol. Soc. 81, 288-300.

794 Wood, S. a., Karp, D.S., DeClerck, F., Kremen, C., Naeem, S., Palm, C. A., 2015. Functional 795 traits in agriculture: agrobiodiversity and ecosystem services. Trends Ecol. Evol. 30,

796 531-539. doi:10.1016/j.tree.2015.06.013 
797 Table 1: Model selection for flower abundance, insect abundance and functional diversity. $N$ 798 corresponds to the number of models selected in the top $4 \mathrm{AIC}_{\mathrm{c}}, \mathrm{R}_{\mathrm{m}}^{2}$ and $\mathrm{R}_{\mathrm{c}}^{2}$ correspond 799 respectively to the marginal and conditional $\mathrm{R}^{2}$ values of the best model. Est. corresponds to 800 the parameter estimate (for centralized and standardized predictor variables), CI to its $95 \%$ 801 confidence interval and Imp. to the parameter relative importance. ${ }^{*}$ Mango field was the 802 reference habitat and ${ }^{\S}$ the dry season was the sampling season of reference.

\begin{tabular}{|c|c|c|c|c|c|c|c|c|c|}
\hline \multirow[b]{2}{*}{ Parameter } & \multicolumn{3}{|c|}{$\begin{array}{c}\text { Flower abundance } \\
(N=\mathbf{2} \text { models }) \\
\mathrm{R}_{\mathrm{m}}^{2}=0.40 ; \mathrm{R}_{\mathrm{c}}^{2}=0.68\end{array}$} & \multicolumn{3}{|c|}{$\begin{array}{c}\text { Insect abundance } \\
(N=6 \text { models }) \\
\mathrm{R}_{\mathrm{m}}^{2}=0.54 ; \mathrm{R}_{\mathrm{c}}^{2}=0.67\end{array}$} & \multicolumn{3}{|c|}{$\begin{array}{l}\text { Functional diversity } \\
\quad(\boldsymbol{N}=\mathbf{6} \text { models }) \\
\mathrm{R}_{\mathrm{m}}^{2}=0.32 ; \mathrm{R}_{\mathrm{c}}^{2}=0.41\end{array}$} \\
\hline & Est. & CI & Imp. & Est. & CI & Imp. & Est. & CI & Imp. \\
\hline Intercept & 2.867 & $\begin{array}{l}(2.056, \\
3.679)\end{array}$ & & 1.402 & $\begin{array}{l}(1.120, \\
1.683)\end{array}$ & & 0.069 & $\begin{array}{l}(0.059, \\
0.082)\end{array}$ & \\
\hline Habitat ${ }^{*}$ & -2.563 & $\begin{array}{l}(-3.033, \\
-2.093)\end{array}$ & 1.00 & 0.255 & $\begin{array}{c}(-0.082, \\
0.592)\end{array}$ & 0.68 & 0.017 & $\begin{array}{l}(0.0002 \\
, 0.033)\end{array}$ & 0.79 \\
\hline Season $^{\S}$ & -1.427 & $\begin{array}{l}(-1.756, \\
-1.098)\end{array}$ & 1.00 & 1.393 & $\begin{array}{l}(1.033, \\
1.751)\end{array}$ & 1.00 & 0.048 & $\begin{array}{l}(0.033, \\
0.063)\end{array}$ & 1.00 \\
\hline Distance & 0.538 & $\begin{array}{l}(0.187, \\
0.889)\end{array}$ & 1.00 & -0.632 & $\begin{array}{l}(-0.940, \\
-0.325)\end{array}$ & 1.00 & -0.026 & $\begin{array}{l}(-0.042, \\
-0.011)\end{array}$ & 1.00 \\
\hline $\begin{array}{c}\text { Habitat } \\
\text { X Season }\end{array}$ & 2.363 & $\begin{array}{l}(1.632, \\
3.093)\end{array}$ & 1.00 & -0.517 & $\begin{array}{l}(-0.962, \\
-0.072)\end{array}$ & 0.55 & 0.015 & $\begin{array}{c}(-0.007, \\
0.038)\end{array}$ & 0.45 \\
\hline $\begin{array}{l}\text { Distance } \\
\text { X Season }\end{array}$ & 0.326 & $\begin{array}{c}(-0.346, \\
0.999)\end{array}$ & 0.35 & 0.687 & $\begin{array}{l}(0.227, \\
1.148)\end{array}$ & 1.00 & -0.006 & $\begin{array}{c}(-0.036, \\
0.023)\end{array}$ & 0.23 \\
\hline $\begin{array}{c}\text { Flower } \\
\text { abundance }\end{array}$ & & & & -0.119 & $\begin{array}{c}(-0.328, \\
0.089)\end{array}$ & 0.39 & & & \\
\hline
\end{tabular}

803

804 
805 Table 2: Model selection for body length, wing span and ratio of wing span over body length.

806 Same legend as Table 1. * Mango field was the reference habitat and ${ }^{\S}$ the dry season was the 807 sampling season of reference.

\begin{tabular}{|c|c|c|c|c|c|c|c|c|c|}
\hline \multirow[b]{2}{*}{ Parameter } & \multicolumn{3}{|c|}{$\begin{array}{c}\begin{array}{c}\text { Body length } \\
(N=7 \text { models })\end{array} \\
\mathrm{R}_{\mathrm{m}}^{2}=0.037 ; \mathrm{R}_{\mathrm{c}}^{2}=0.45\end{array}$} & \multicolumn{3}{|c|}{$\begin{array}{c}\begin{array}{c}\text { Wing span } \\
(N=7 \text { models })\end{array} \\
\mathrm{R}_{\mathrm{m}}^{2}=0.015 ; \mathrm{R}_{\mathrm{c}}^{2}=0.54\end{array}$} & \multicolumn{3}{|c|}{$\begin{array}{c}\text { Ratio of wing span } \\
\text { over body length } \\
(\boldsymbol{N}=\mathbf{5} \text { models }) \\
\mathrm{R}_{\mathrm{m}}^{2}=0.02 ; \mathrm{R}_{\mathrm{c}}^{2}=0.40\end{array}$} \\
\hline & Est. & CI & Imp. & Est. & CI & Imp. & Est. & CI & Imp. \\
\hline Intercept & 0.556 & $\begin{array}{l}(0.271, \\
0.840)\end{array}$ & & 0.805 & $\begin{array}{l}(0.433, \\
1.177)\end{array}$ & & 0.248 & $\begin{array}{l}(0.155, \\
0.342)\end{array}$ & \\
\hline Habitat ${ }^{*}$ & 0.049 & $\begin{array}{c}(0.0007, \\
0.097)\end{array}$ & 0.89 & 0.052 & $\begin{array}{l}(0.006, \\
0.099)\end{array}$ & 0.93 & -0.0004 & $\begin{array}{c}(-0.013, \\
0.013)\end{array}$ & 0.24 \\
\hline Season $^{\S}$ & 0.168 & $\begin{array}{l}(0.112, \\
0.225)\end{array}$ & 1.00 & 0.126 & $\begin{array}{c}(0.067 \\
0.186)\end{array}$ & 1.00 & -0.042 & $\begin{array}{l}(-0.061, \\
-0.022)\end{array}$ & 1.00 \\
\hline Distance & -0.047 & $\begin{array}{c}(-0.109, \\
0.014)\end{array}$ & 0.68 & -0.018 & $\begin{array}{c}(-0.095, \\
0.028)\end{array}$ & 0.52 & 0.002 & $\begin{array}{c}(-0.011, \\
0.015)\end{array}$ & 0.28 \\
\hline $\begin{array}{c}\text { Habitat } \\
\text { X Season }\end{array}$ & -0.023 & $\begin{array}{l}(-0.10, \\
0.053)\end{array}$ & 0.32 & -0.008 & $\begin{array}{c}(-0.097, \\
0.048)\end{array}$ & 0.32 & 0.003 & $\begin{array}{c}(-0.019, \\
0.025)\end{array}$ & 0.07 \\
\hline $\begin{array}{l}\text { Distance } \\
\text { X Season }\end{array}$ & 0.060 & $\begin{array}{l}(0.004, \\
0.117)\end{array}$ & 0.53 & 0.016 & $\begin{array}{c}(-0.011, \\
0.109)\end{array}$ & 0.32 & -0.009 & $\begin{array}{c}(-0.028, \\
0.009)\end{array}$ & 0.10 \\
\hline
\end{tabular}

809 


\section{$810 \quad$ Figures}

811 Figure 1: Effect of distance to the natural habitat (m), habitat type and sampling period on: A.

812 abundance of flowers $(\log +1)$, B. abundance of insects, and C. functional diversity of insects.

813 Lines represent model predicted values. In all panels, mango flowering period (dry season) is

814 represented in dark grey and mango non-flowering period (wet season) is represented in light

815 grey.

816

817 Figure 2: Relationship between body length ( $\mathrm{mm})$ and wing span ( $\mathrm{mm}$ ) of flying insects (A),

818 and effect of distance to the natural habitat $(\mathrm{m})$ and habitat type on insect body length (B).

819 Mango flowering period (dry season) is represented in dark grey and mango non-flowering

820 period (wet season) is represented in light grey. 
$822 \quad$ Figure 1
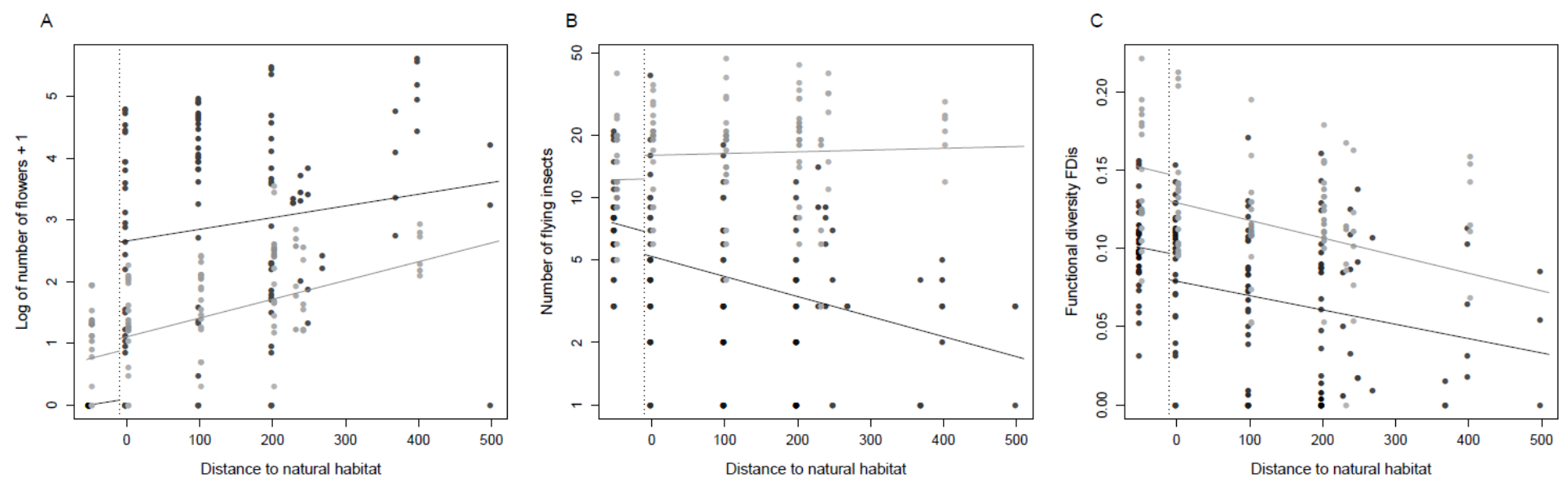

823 
824 Figure 2

A

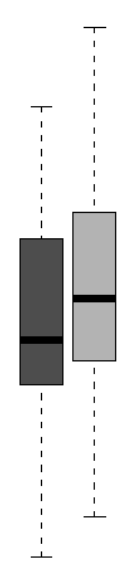

825

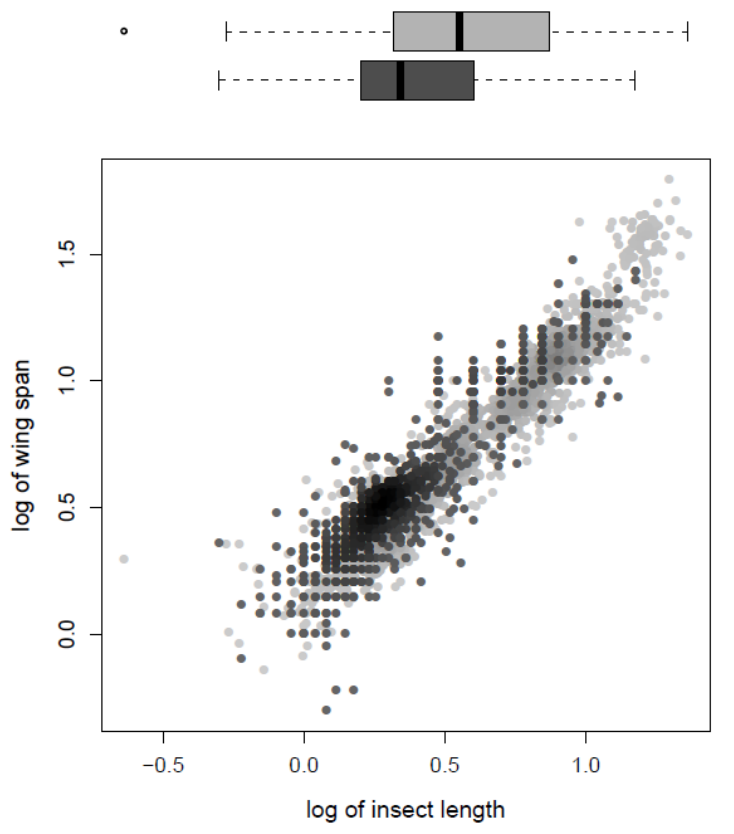

B

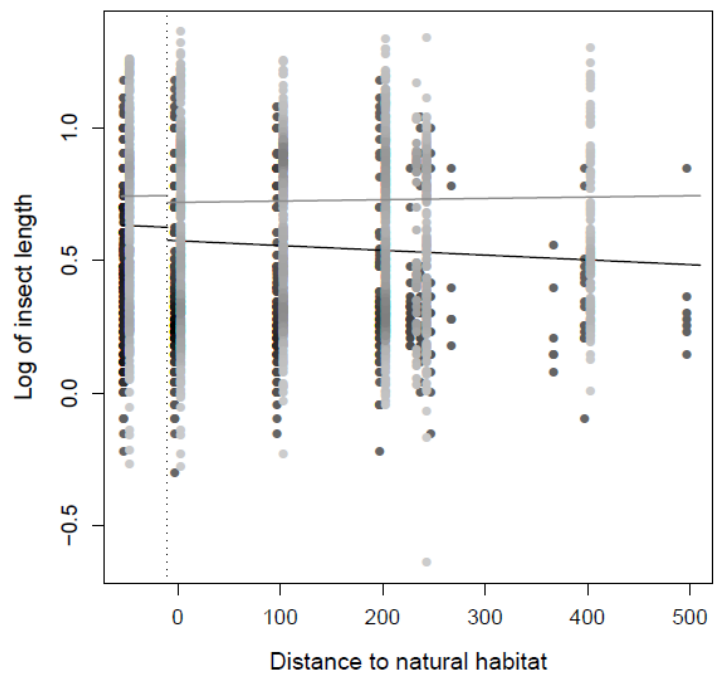

